\title{
POTENSI KANDUNGAN KIMIAWI DARI UBI JALAR UNGU (IPOMOEA BATATAS L) SEBAGAI BAHAN IDENTIFIKASI KEBERADAAN PLAK PADA PERMUKAAN GIGI
}

\author{
Endah Aryati Ekoningtyas $^{\varpi 1}$, Triwiyatini ${ }^{2}$, Fahrun Nisa ${ }^{3}$
}

\begin{abstract}
ABSTRAK
Pada permukaan gigi selalu terbentuk lapisan transparan yang melekat erat yang dikenal sebagai lapisan Plak gigi. Plak di permukaan gigi dapat dipakai sebagai salah satu indikator kebersihan mulut. Untuk mengetahui keberadaan plak dibutuhkan bahan pewarna yang dapat mewarnai permukaan plak. Ubi jalar ungu memiliki zat pewarna alami yaitu antosianin. Penelitian ini bertujuan untuk mengetahui potensi kandungan kimiawi dari ubi jalar ungu (ipomoea batatas l,) sebagai bahan identifikasi keberadaan plak

Penelitian ini menggunakan metode penelitian Eksperimental Research. Desain penelitian yang digunakan dalam penelitian ini adalah Posttest Only Design. Pengambilan sampel secara Total Sampling dan jumlah responden sebanyak 30 orang. Seluruh respondendikenai dua kali perlakuan yaitu mendapat penetesan larutan ubi jalar ungu dan penetesan bahan disclosing solution sebagai kontrol positif dengan waktu yang berbeda.

Hasil penelitian menunjukkan bahwa bahan ubi jalar dapat digunakan sebagai bahan identifikasi keberadaan plak di permukaan gigi dan dari Uji statistic uji Independent $t$ test, didapatkan $p<0,000$ artinya ada perbedaan pengaruh antara bahan ubi jalar ungu dengan bahan disclosing solution sebagai bahan identifikasi keberadaan plak gigi. Untuk penelitian lebih lanjut disarankan agar dapat melakukan pewarnaan yang maksimal pada permukaan plak maka mengupayakan agar bahan pewarna antosianin memiliki konsentrasi yang lebih pekat.
\end{abstract}

Kata kunci : Ubi Jalar Ungu (ipomoea batatas l), Identifikasi keberadaan, Plak Gigi

\begin{abstract}
On dental surface always been formed a transparent layer which firmly attached, known as dental plaque layer. Plaque on the tooth surface can be used as one indicator of oral hygiene. To determine the presence of plaque necessary dyes which can stain the surface of the plaque. Purple sweet potato has a natural dye that is anthocyanin. This study aims to determine the potential of the chemical content of purple sweet potato (ipomoea batatas $l$,) as the material identification of the presence of plaque

This study research method was Experimental Research and Posttest Only Design as research approach. Sampling used with total Sampling methods and the number of respondents was 30 people. All respondents subjected twice treatment who gets purple sweet potato solution and hatching materials disclosing solution as a positive control at different times.

Results showed Purple sweet potato can be used as identification of the presence of plaque on the tooth surface and of the test statistic test Independent $t$ test, obtained $p<0.000$ means there are differences of influence between the material of purple sweet potato with materials disclosing solution as the material identification of the presence of dental plaque. Further research is recommended in order to do the maximum staining on the surface of the plaque then seek to have the concentration of anthocyanin dyes are more concentrated.
\end{abstract}

Keywords : purple sweet potato (ipomoea batatas l), identification ability, dental plaque

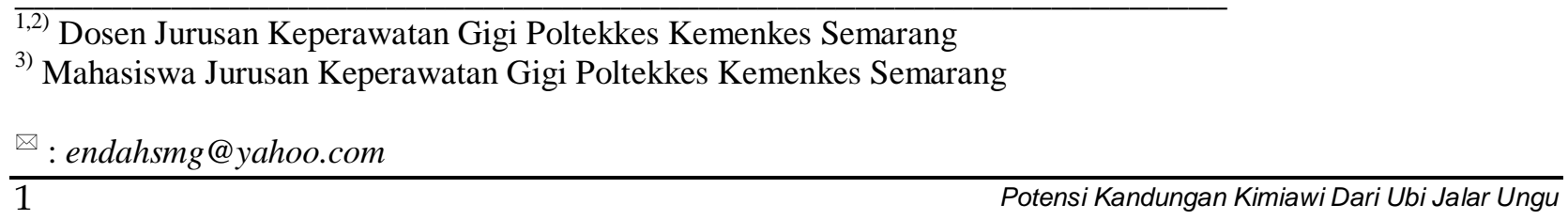




\section{PENDAHULUAN}

Pada permukaan gigi selalu terbentuk lapisan transparan yang melekat erat yang dikenal sebagai lapisan Plak gigi. Beberapa saat kemudian pada lapisan tersebut terdiri atas bakteri dan produk-produknya dalam bentuk bahan organik dan anorganik, cairan mulut, sel epitel yang lepas dan sel darah (Armasastra, 2011). Dinyatakan pula bahwa plak gigi merupakan biofilm, yang berupa komunitas bakteri yang terorganisasi dengan baik, melekat kuat pada struktur organik maupun anorganik dan sulit dilepaskan dengan hanya berkumur Overman (2005).

Plak di permukaan gigi dapat dipakai sebagai salah satu indikator kebersihan mulut. Pembersihan yang kurang baik dapat menyebabkan plak semakin melekat dan menjadi karang gigi setelah mengalami kalsifikasi (Hamsar 2006). Untuk mengetahui keberadaan plak yang terbentuk sejak sesaat kontak dengan cairan rongga mulut dibutuhkan bahan pewarna yang dapat mewarnai komponen yang melekat pada permukaan plak tersebut. Plak akan lebih terlihat berwarna abu-abu, kekuningan bila plak telah matang dan menumpuk serta biasanya ditemui pada sepertiga permukaan gingival dan pada permukaan gigi yang cacat dan kasar (Putri, dkk, 2011)

Zat yang digunakan untuk melihat plak biasanya mempunyai warna kontras dengan warna gigi. Dengan menggunakan disclosing atau zat pewarna dapat dengan mudah memberitahu atau mengarahkan pasien akan adanya plak dan dapat menunjukkan bersih tidaknya hasil penyikatan gigi yang telah dilakukannya. Syarat disclosing agent sebagai zat pewarna plak adalah : (1) Dapat memberi warna terhadap plak secara selektif sehingga tidak mempengaruhi daerah gigi dan daerah sekitar gigi yang bersih, (2) Tidak mengubah warna dari struktur mulut yang lain, seperti pipi bibir dan lidah, (3) Tidak boleh mempengaruhi rasa, (4) Tidak memberi efek yang berbahaya bila tertelan dan tidak boleh menimbulkan reaksi alergi.
Ubi jalar ungu merupakan makanan tradisional yang memiliki manfaat bagi kesehatan. Ubi jalar ungu mempunyai komposisi gizi dan fisiologis yang bagus bagi kesehatan tubuh. Pigmen ungu pada ubi ungu bermanfaat sebagai antioksidan karena dapat menyerap polisi udara, racun, oksidan dalam tubuh dan menghambat penggumpalan sel-sel darah. Ubi jalar ungu mengandung senyawa antosianin yang berfungsi sebagai antioksida, antikanker, antibakteria, serta perlindungan terhadap kerusakan hati, jantung dan stroke. Jumlah kandungan antosianin bervariasi pada setiap tanaman dan berkisar antara 20mg/100gr untuk 600 $\mathrm{mg} / 100 \mathrm{gr}$ berat basa (Siswoyo, 2013).

Warna ungu pada ubi jalar disebabkan oleh adanya pigmen antosianin yang tersebar dari bagian kulit sampai ke daging umbinya (Khaldun, dkk, 2013). Kandungan antosianin yang tinggi pada ubi jalar ungu mempunyai stabilitas yang tinggi dibanding antosianin dari sumber lain. Itulah sebabnya tanaman ini menjadi pilihan yang lebih sehat dan sebagai alternatif pewarnaan alami (Samber dkk, 2013). Antosianin merupakan sub-tipe senyawa organik dari golongan flavonoid. Beberapa senyawa antosianin yang paling banyak ditemukan adalah pelargonidin, peonidin, sianidin, malvidin, petunidin dan delfinidin (Khaldun, dkk, 2013). Kandungan antosianin yang tinggi pada ubi jalar ungu mempunyai stabilitas yang tinggi dibanding antosianin dari sumber lain. Itulah sebabnya tanaman ini menjadi pilihan yang lebih sehat dan sesuai dengan alternatif pewarna alami (Siswoyo, 2013).

Penelitian ini bertujuan untuk mengetahui potensi kandungan kimiawi dari ubi jalar ungu (ipomoea batatas $l$ ) sebagai bahan identifikasi keberadaan plak.

\section{METODE PENELITIAN}

Penelitian ini menggunakan metode penelitian Eksperimental Research atau percobaan yang bertujuan untuk mengetahui 
suatu gejala atau pengaruh timbul sebagai akibat dari adanya perlakuan tertentu (Notoatdmojo, 2010).

Desain penelitian yang digunakan dalam penelitian ini adalah Posttest Only Design. Dengan rancangan ini, hanya memberikan informasi yang bersifat deskriptif. Bentuk rencana penelitian tersebut digunakan sebagai berikut :

Tabel 1. Bentuk Rencana Penelitian

\begin{tabular}{cc}
\hline Eksperimen & Posttest \\
\hline $\mathrm{X}$ & $0 \mathrm{~A}$ \\
\hline $\mathrm{Y}$ & $0 \mathrm{~B}$
\end{tabular}

Keterangan :

$\mathrm{X}$ : Perlakuan pengolesan cairan sari ubi jalar ungu pada seluruh permukaan gigi.

Y : Perlakuan pengolesan cairan larutan disclosing solution pada seluruh permukaan gigi.

0A : Observasi apakah plak dapat terlihat atau tidak terlihat, setelah pengolesan pada seluruh permukaan gigi dengan cairan sari ubi jalar ungu.

OB : Observasi apakah plak dapat terlihat atau tidak terlihat, setelah pengolesan cairan larutan disclosing solution.

Pengambilan sampel secara Total Sampling dan jumlah responden sebanyak 30 orang. Seluruh responden dikenai dua kali perlakuan yaitu mendapat penetesan larutan ubi jalar ungu dan penetesan bahan disclosing solution sebagai kontrol positif dengan waktu yang berbeda. Sebelumnya responden diberi instruksi untuk menyikat gigi kemudian ditunggu selama 7 menit.

Pada penelitian ini menggunakan sari ubi jalar ungu. Cara pengambilan sari ubi jalar ungu yaitu tanaman ubi jalar ungu sebanyak 400 gram dipisahkan dari kulitnya, setelah dikupas mendapatkan berat sebanyak 200 gram, kemudian dihaluskan dan diambil sarinya sebanyak $75 \mathrm{ml}$.
Dalam penelitian ini variabel terpengaruhnya adalah skor plak. Pengukurannya menggunakan Indeks plak PHP. Cara pemeriksaan klinis pada plak yang ditentukan berdasarkan indeks plak PHP adalah sebagai berikut :

a. Digunakan bahan pewarna gigi untuk memeriksa plak yang terbentuk pada permukaan mahkota gigi.

b. Pemeriksaan plak dilakukan pada permukaan mahkota gigi bagian fasial atau lingual dengan membagi tiap permukaan mahkota gigi menjadi lima subdivisi. Gigi indeks dan permukaan gigi yang di ukur :

Tabel 2. Gigi indeks dan permukaan gigi yang diukur

\begin{tabular}{|c|c|c|}
\hline $\begin{array}{r}16: \text { Buccal }+ \\
\text { Palatinal }\end{array}$ & $\begin{array}{r}\text { 11: Labial }+ \\
\quad \text { Palatinal }\end{array}$ & $\begin{array}{r}26: \text { Buccal }+ \\
\text { Palatinal }\end{array}$ \\
\hline $\begin{array}{r}46: \text { Buccal }+ \\
\text { Lingual }\end{array}$ & $\begin{array}{r}31: \text { Labial }+ \\
\text { Lingual }\end{array}$ & $\begin{array}{r}36: \text { Buccal }+ \\
\text { Lingual }\end{array}$ \\
\hline
\end{tabular}

c. Cara penilaian plak adalah sebagai berikut:

Nilai $0=$ tidak ada plak

Nilai $1=$ terdapat plak

d. Cara pengukuran untuk menentukan indeks plak PHP yaitu dengan rumus dibawah ini dan nilai yang dihasilkan adalah berupa angka

IP PHP $=\frac{\text { Jumlah skor plak seluruh permukaan gigi yang diperiksa }}{\text { Jumlah gigi yang diperiksa }}$ Jumlah gigi yang diperiksa

e. Kriteria penilaian tingkat kebersihan mulut berdasarkan indeks plak PHP (Personal Hygiene Performance), yaitu :

Baik $=0-1,7$

Sedang $=1,8-3,4$

Buruk $=3,5-5$

Data hasil penelitian disajikan secara deskriptif kuantitatif yaitu mendeskripsikan hasil penelitian ke dalam tabel. Adapun untuk mengetahui efektifitas ubi jalar (Ipomea Batatas L,) ungu sebagai bahan disclosing solution (bahan identifikasi plak) menggunakan uji Independent t test. 


\section{HASIL DAN PEMBAHASAN}

Gambaran secara deskriptif distribusi frekuensi kriteria indeks plak setelah mendapat perlakuan adalah sebagai berikut :

Tabel 3. Distribusi frekuensi kriteria Indeks Plak setelah pengolesan Ubi Jalar Ungu

\begin{tabular}{cccc}
\hline \multirow{2}{*}{ No } & \multirow{2}{*}{ Kriteria } & \multicolumn{2}{c}{$\begin{array}{c}\text { Pengolesan } \\
\text { ubi jalar ungu }\end{array}$} \\
\cline { 3 - 4 } & & $\mathrm{N}$ & $\%$ \\
\hline 1 & Baik $(0-1.7)$ & 0 & $0 \%$ \\
2 & Sedang $(1.8-3.4)$ & 28 & $93 \%$ \\
3 & Buruk $(3.5-5)$ & 2 & $7 \%$ \\
\hline & Jumlah & 30 & $100 \%$ \\
\hline
\end{tabular}

Pada tabel 3 terlihat bahwa setelah penetesan ubi jalar bisa menunjukkan identifikasi keberadaan plak, yaitu dari 30 responden menunjukkan kriteria sedang sebesar $93 \%$.

Tabel 4. Distribusi frekuensi kriteria Indeks Plak setelah pengolesan disclosing solution

\begin{tabular}{|c|c|c|c|}
\hline \multirow[t]{2}{*}{ No } & \multirow[t]{2}{*}{ Kriteria } & \multicolumn{2}{|c|}{$\begin{array}{c}\text { Pengolesan } \\
\text { disclosing solution }\end{array}$} \\
\hline & & $\mathrm{N}$ & $\%$ \\
\hline 1 & Baik $(0-1.7)$ & 0 & $0 \%$ \\
\hline 2 & Sedang $(1.8-3.4)$ & 6 & $20 \%$ \\
\hline 3 & Buruk $(3.5-5)$ & 24 & $80 \%$ \\
\hline & Jumlah & 30 & $100 \%$ \\
\hline
\end{tabular}

Dari tabel 4, terlihat bahwa penetesan menggunakan bahan yang biasa digunakan di kedokteran gigi menunjukkan keberadaan plak buruk lebih banyak (80\%). Hal ini berbeda pada penetesan menggunakan larutan ubi jalar ungu.

Hasil penelitian selanjutnya dilakukan uji statistic uji Independent $t$ test untuk mengetahui perbedaan antara dua kelompok perlakuan tersebut sebagai berikut :
Tabel 5. uji Independent t test

\begin{tabular}{|c|c|c|c|c|c|}
\hline \multirow[t]{2}{*}{$\mathrm{t}$} & \multirow[t]{2}{*}{ df } & \multirow[t]{2}{*}{$\begin{array}{c}\text { Sig. } \\
\text { (2-tailed) }\end{array}$} & \multirow[t]{2}{*}{$\begin{array}{c}\text { Mean } \\
\text { Difference }\end{array}$} & \multicolumn{2}{|c|}{$\begin{array}{l}95 \% \text { Confidence } \\
\text { Interval of } \\
\text { the Difference }\end{array}$} \\
\hline & & & & Lower & Upper \\
\hline 37.718 & 59 & .000 & 2.43333 & 2.3042 & 2.5624 \\
\hline
\end{tabular}
test menunjukkan bahwa terdapat perbedaan yang signifikan pada penggunaan ubi jalar ungu dan bahan disclosing solution sebagai bahan identifikasi plak pada permukaan gigi

\section{PEMBAHASAN}

Plak di permukaan gigi dapat dipakai sebagai salah satu indikator kebersihan mulut, plak memiliki sifat melekat pada permukaan gigi (Hamsar 2006). Dalam jumlah sedikit plak tidak dapat terlihat kecuali apabila telah diwarnai dengan bahan pewarna. Dijelaskan pula bahwa plak adalah suatu biofilm sendiri diartikan sebagai komunitas bakteri yang terorganisasi dengan baik, melekat kuat pada struktur organik maupun anorganik dan sulit dilepaskan dengan hanya berkumur.

Tabel 3 dan Tabel 4 menunjukkan bahwa bahan pewarna baik yang bahan dasar kimiawi (disclosing) ataupun berupa komponen bahan pewarna alami dari tanaman (ubi jalar ungu) bisa menunjukkan keberadaan plak gigi yang ada di permukaan gigi.

Untuk menunjukkan ada perbedaan pengaruh kedua bahan tersebut sebagai bahan identifikasi keberadaan plak gigi pada Tabel 5, Uji statistik uji Independent t test, didapatkan $\mathrm{p}<0,000$, artinya terdapat perbedaan yang signifikan pada penggunaan ubi jalar ungu dan bahan disclosing solution sebagai bahan identifikasi plak pada permukaan gigi.

Diketahui bahwa ikatan yang terjadi antar atom pada suatu senyawa berkaitan dengan interaksi atau gaya intramolekuler (intramolecularforce), yaitu gaya yang mengikat atom-atom dalam satu molekul akibat adanya ikatan kimia. 
Pada penelitian ini dilakukan penetesan setelah 7 menit responden menyikat gigi maka dimungkinkan yang terbentuk adalah lapisan pelikel, yang mengandung komponen saliva yaitu suatu protein, glikorotein. Glikoprotein adalah suatu protein yang mengandung rantai oligosakarida yang mengikat glikan dengan ikatan kovalen. Hal ini membuat plak gigi memiliki kemampuan untuk menahan sejumlah besar substansi larutan yang digunakan sebagai disclosing solution. Hal ini berkaitan dengan interaksi antara plak dan larutan (dyes) karena adanya perbedaan polaritas antara komponen plak dan larutan. Yaitu adanya sifat dari bahan iodin yang memiliki sifat elektronegativitas yang tinggi, artinya memiliki kemampuan untuk berikatan.

Sedangkan pada ubi jalar ungu, kandungan zat warnanya adalah Antosianin yaitu pigmen pewarna yang memiliki sifat larut dalam air (Koswara, 2009). Dimana pada lingkungan gigi terdapat cairan rongga mulut sehingga kemampuan ubi jalar ungu ini memiliki kemampuan berikatan dengan dengan cairan di sekeliling keberadaan plak, sehingga tidak kuat berikatan dengan glikoprotein yang merupakan komponen utama dalam plak baru terbentuk pada penelitian ini.

\section{KESIMPULAN}

Bahan ubi jalar dapat digunakan sebagai bahan identifikasi keberadaan plak di permukaan gigi dan dari Uji statistic uji Independent $t$ test, didapatkan $p<0,000$ artinya ada perbedaan pengaruh antara bahan ubi jalar ungu dengan bahan disclosing solution sebagai bahan identifikasi keberadaan plak gigi. Untuk penelitian lebih lanjut disarankan agar mengupayakan mendapatkan bahan antosianin sebagai bahan dasar pewarna dengan konsentrasi yang lebih pekat.

\section{DAFTAR PUSTAKA}

Armasastra, B., 2011, Paradigma Baru Pencegahan Karies Gigi, Lembaga Penerbit Fakultas Ekonomi Universitas Indonesia, Jakarta.

--------, 2007, Agro industri dan pangan, tentang karoten, http://ptp.Wordpres.com/2007/09/19, Pewarna-Alami, Diunduh tanggal 09 Desember 2014.

Hamsar, A. 2006, Perbandingan Sikat Gigi yang Berbulu Halus (Soft) dengan Sikat Gigi Berbulu Sedang (Medium) Terhadap Manfaatnya menghilangkan Plak Pada Anak Usia 9 -12 tahun di SD negeri 060830 Kecamatan Medan Petisah tahun 2005. Jurnal Ilmiah Panmed. Vol. 1, No. 1, Medan.

Khaldun, I., Erlidawati, dan Munzair. Kestabilan zat warna alami dan umbi ketela ungu. Chima Didactica Acta.2013. 1(1) .34-40.

Koswara, S., 2009, Pewarna Alami : Produksi dan Penggunaannya, produksi eBookPangan.com

Nugraheni, M., 2012, Pewarna Alami dan Potensi Fungsionalnya, http://staff.uny.ac.id/sites/default/files /penelitian/dr-mutiara-nugrahenistpmsi/pewarna-alami-dan-potensifungsionalnya-makalah-semnas20122. pdf, Diunduh 4/06/2015

Overman, P.R. 2000, Biofilm : A New View of Plaque. J Contemp Dent. Pract 2000, 15;1(3);18-29.

Pratiwi, A I., 2014, Manfaat Berkumur Sari Buah Delima Merah Terhadap Penurunan Akumulasi Plak. Unmaslibrary. ac. id/ wp-content/ uploads /2014/04/SKRIPSI 3.pdf 
Putri, M.H., Herijulianti E, dan Nurjanah N., 2011. Ilmu Pencegahan Penyakit Jaringan Keras dan Jaringan Pendukung Gigi, EGC, Jakarta.

Samber NL, Semangun H, Prasetyo B., 2013, Ubi Jalar Ungu Рapua Sebagai Sumber Antioksidan. Jurnal, Fjip, uns. ac. id/index. Php/ probio/ article /view /3210. di akses pada tanggal 9 Desember 2014. 